\title{
RELATION BETWEEN EDUCATION AND TOURISTS PERCEPTION ABOUT PILGRIMAGE TOURISM - A STUDY WITH REFERENCE TO NORTH GUJARAT
}

\author{
Ms. Rajpriya Laxmichand Patel
}

\author{
Assistant Professor, \\ Shankersinh Vaghela Bapu Institute of Science \& Commerce \\ Gandhinagar
}

\begin{abstract}
Modern tourism is not includes only religious and personal tourism but also business tourism, international tourism and intelligence tourism. Pilgrimage tourism plays very important role in tourism sector. "Religious tourism" highlights the travels triggered by religious sentiments. Hinduism, Christianity, Islam, Jainism, Buddhism, people with Heart beliefs in religion travel to different places quite regularly. Millions of people all over the world undertake annual pilgrimages to different places of worship. This paper deals with relation between Education and tourists' perception about pilgrimage tourism of North Gujarat region. North Gujarat is also having many pilgrimage cities so it is become very important to know the perception about pilgrimage tourism with reference to North Gujarat.
\end{abstract}

Key words: - Education, Pilgrimage, Tourism, Tourist's perception, Religious Tourism.

\section{INTRODUCTION}

Religious tourism is one of the earliest forms of tourism. The idea of the religious pilgrimage begins almost with the dawn of humanity. Religious oriented travel then has occurred since the first pilgrimages. In recent years however, religious travel and tourism has developed into a much larger and more segmented market. Today's religious travel includes multiple sub-niches that range from the luxury pilgrimage market to backpacking and from religious institutional travel to volunteer oriented experiences meant to help those in some form of need. Religious tourism also commonly referred to as faith tourism, is a type of tourism, where people travel individually or in groups for pilgrimage, missionary, or fellowship purpose. The world's largest form of mass religious tourism takes place at the annual Hajj pilgrimage in Mecca, Saudi Arabia. Religious tourism is one of the earliest forms of tourism. The idea of the religious pilgrimage begins almost with the dawn of humanity. Almost since the dawn of history human beings have travelled to holy sites. By the biblical period important religious centers had become not only a part of the cultural landscape, but they also had become major players in local marketing and important parts of the economy of those cities that hosted religious centers.

\section{REVIEW OF LITERATURE}

World Tourism Organization (2011); World Tourism Organization in this article described religious tourism in Asia and Pacific. Many countries include religion in their census. From this article I come to know that approximately six hundred million national and international religious in the world of which $40 \%$ take place in Europe and around half in Asia. Asia and Pacific forms the hub of Pilgrim Centres. This article recommended improving existing policies, strategies and marketing programmes for religious tourist; innovations of religious tourism and creation of new inter regional markets for religious purposes and also enhancing the potential tourist's knowledge.

Mehri Yasami (2013, Bangkok, Thailand); The purpose of this study was to investigate the perception of International tourists toward Iran's culture and their intentions to visit that country. From this research I found that 295 questionnaires were selected to be used in this research and overall, the respondents perceived Iran's culture positively. Key finding of the study can be summarized in four ways 1) Tourists positive perception towards Iran's culture, where classified by gender there were no significant difference. The past visit experience, relationship between tourists' perception and visit intentions is disclosed. The results of the study revealed that tourism marketers are aware of tourist attributes due to their impacts on the tourist's destination choices.

Shambhu K.C. \& Jhabindra Gewali (2014) (Bachelor of Business Administration); The Socio-economic impacts of faith tourism in Lumbini region in Nepal is identify, select and analyze in this study. Lumbini region is the birthplace of Buddha but the development has not been progressed as has been expected. Societies in Lumbini region are yet deprived even thought there are many potential resources. In this study It is highlighted 


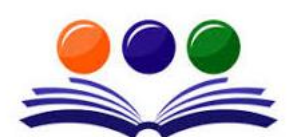

GRAND ACADEMIC PORTAL RESEARCH JOURNALS

\section{A GLOBAL JOURNAL OF SOCIAL SCIENCES}

( ISSN - 2581-5830 )

Impact Factor: SJIF - 4.998, IIFS - 4.375

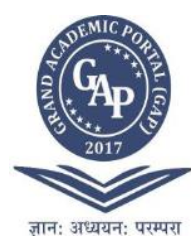

sample representative of the entire universe i.e. North Gujarat. A source used for data collection in the present research study is;

Primary Data: The present research study is mainly based on the primary sources of information collected through field work. The primary data has been collected by visiting tourist places and conducting interviews with tourists with the help of multiple choice questionnaires.

Analysis and Interpretation of Data: Keeping in view the objectives of the study, the data collected through the multiple choices and open ended questionnaire has been classified and tabulated. Data in the tables have been analyzed and interpreted with the help of statistical techniques. The statistical analysis of the collected information is presented in terms of frequency and percentage. The researcher has done variety data analysis and tabulated the data in cross tabulation to study the respondent's opinion about selected variables such as attractions of tourist resources, package tours, accommodation facilities, public transport, tourist complexes, food services, promotional services, prices charged for the facilities and suggestions for improving tourism service. The relationship between selected attributes/variables have been tested using statistical test named "chi-square test" and level of significance is fixed at $5 \%$ cut of point.

\section{LIMITATIONS OF THE STUDY}

- The size of the sample is limitation as it is not possible to reach to all tourists in the sample.

- Because of time and cost constraints, it is not be possible to visit all the places, hence the researcher has selected only north Gujarat and thus the result may not represent the entire nation.

- Non-available of useful data on some aspects may restrict the research study to certain limitations.

- The researcher based on primary data so it would be depends on respondent's readiness and awareness for the study.

- The tourist generally defers in their opinions. Sometimes the difference may be very high in their opinions.

Table-1: Distribution of respondents according to their education.

\begin{tabular}{|c|c|c|c|}
\hline Sr No & Education & Frequency & Percentage \\
\hline 1 & Metric & 32 & $16 \%$ \\
\hline 2 & Graduate & 50 & $25 \%$ \\
\hline 3 & Post graduate & 48 & $24 \%$ \\
\hline 4 & Professional course & 32 & $16 \%$ \\
\hline 5 & Diploma & 38 & $19 \%$ \\
\hline $\mathbf{6}$ & Total & $\mathbf{2 0 0}$ & $\mathbf{1 0 0 \%}$ \\
\hline
\end{tabular}

Source: Questionnaire, Question no.7

From above table 1, it can be said that there are 50(25\%) respondents who are graduate, $48(24 \%)$ respondents are post graduate, $38(19 \%)$ are Diploma and 32(16\%) are Metric holder and professional.

Table-1.1: Distribution of respondents according to type of tourist place and their education.

\begin{tabular}{|c|c|c|c|c|c|c|}
\hline Type of Place & Metric & Graduate & Post Graduate & professional & Diploma & Total \\
\hline Bindusarovar & 2 & 7 & 9 & 9 & 3 & 30 \\
\hline Ma Umiya & 8 & 7 & 10 & 5 & 5 & 35 \\
\hline Ma Ambaji & 7 & 11 & 7 & 3 & 7 & 35 \\
\hline Bahucharaji & 5 & 6 & 5 & 7 & 7 & 30 \\
\hline Magarvada & 4 & 9 & 10 & 4 & 8 & 35 \\
\hline Miradatar & 6 & 10 & 7 & 4 & 8 & 35 \\
\hline Total & 32 & 50 & 48 & 32 & 38 & 200 \\
\hline
\end{tabular}

Source: Questionnaire, Question no. 1 \& 7

Ho: There is no significant difference between education of respondents and place selection.

$\mathrm{H}_{1}$ : There is significant difference between education of respondents and place selection.

Chi square value $=16.6$ with DF $20, \mathrm{X}^{2} \mathrm{C}=16.6$, at $5 \%$ level of significance with $20 \mathrm{DF} \mathrm{X}{ }_{\mathrm{T}}=31.410$, Here, $\mathrm{X}^{2} \mathrm{c}^{<}$ $\mathrm{X}^{2} \mathrm{~T}$, Hence Ho is accepted, so we can say that there is no significant difference between education of respondents and place selection. 


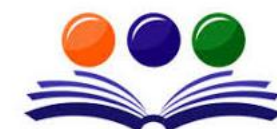

GRAND ACADEMIC PORTAL RESEARCH JOURNALS
A GLOBAL JOURNAL OF SOCIAL SCIENCES

( ISSN - 2581-5830 )

Impact Factor: SJIF - 4.998, IIFS - 4.375

Table-1.2: Distribution of respondents according to their education and transport facilities opinion.

\begin{tabular}{|c|c|c|c|c|}
\hline \multirow{2}{*}{ Education } & \multicolumn{3}{|c|}{ Opinion about Transport facilities } & \multirow{2}{*}{ Total } \\
\cline { 2 - 4 } & Satisfied & Neutral & Dissatisfied & \\
\hline Metric & 14 & 8 & 10 & $\mathbf{3 2}$ \\
\hline Graduate & 41 & 4 & 5 & $\mathbf{5 0}$ \\
\hline Post graduate & 39 & 3 & 6 & $\mathbf{4 8}$ \\
\hline Professional & 13 & 10 & 9 & $\mathbf{3 2}$ \\
\hline Diploma & 24 & 5 & 9 & $\mathbf{3 8}$ \\
\hline Total & $\mathbf{1 3 1}$ & $\mathbf{3 0}$ & $\mathbf{3 9}$ & $\mathbf{2 0 0}$ \\
\hline
\end{tabular}

Source: Questionnaire, Question no. 7 \& 13.

Ho: There is no significant difference between education of respondents and their opinion about transportation facilities.

$\mathrm{H}_{1}$ : There is significant difference between education of respondents and their opinion about transportation facilities.

Chi square value $=28.5$ with $\mathrm{DF} 8, \mathrm{X}^{2} \mathrm{C}=28.5$, at $5 \%$ level of significance with $8 \mathrm{DF} \mathrm{X}_{\mathrm{T}} \mathrm{T}=15.507$

Here, $\mathrm{X}^{2}{ }_{\mathrm{C}}>\mathrm{X}^{2} \mathrm{~T}$, hence Ho is rejected. So we can say that there is significant difference between education of respondents and their opinion about transportation facilities.

Table-1.3: Distribution of respondents according to their education and opinion about facilities of tourist complexes.

\begin{tabular}{|c|c|c|c|c|}
\hline \multirow{2}{*}{ Education } & \multicolumn{2}{|c|}{ Opinion about facilities of tourist complexes. } & \multirow{2}{*}{ Total } \\
\cline { 2 - 5 } & Satisfied & Neutral & Dissatisfied & \\
\hline Metric & 13 & 10 & 9 & $\mathbf{3 2}$ \\
\hline Graduate & 40 & 3 & 7 & $\mathbf{5 0}$ \\
\hline Post graduate & 41 & 2 & 5 & $\mathbf{4 8}$ \\
\hline Professional & 12 & 9 & 11 & $\mathbf{3 2}$ \\
\hline Diploma & 21 & 8 & 9 & $\mathbf{3 8 0}$ \\
\hline Total & $\mathbf{1 2 7}$ & $\mathbf{3 2}$ & $\mathbf{4 1}$ & \\
\hline
\end{tabular}

Source: Questionnaire, Question no. 7 \& 15.

Ho: There is no significant difference between education of respondents and their opinion about facilities of tourist complexes.

$\mathrm{H}_{1}$ : There is significant difference between education of respondents and their opinion about facilities of tourist complexes.

Chi square value $=35.3$ with $\mathrm{DF} 8, \mathrm{X}^{2} \mathrm{C}=35.3$, at $5 \%$ level of significance with $8 \mathrm{DF} \mathrm{X}_{\mathrm{T}}=15.507$

Here, $\mathrm{X}^{2}{ }_{\mathrm{c}}>\mathrm{X}^{2} \mathrm{~T}$, hence Ho is rejected. So we can say that there is significant difference between education of respondents and their opinion about facilities of tourist complexes.

Table-1.4: Opinion of respondents about quality of food service.

\begin{tabular}{|l|c|c|c|c|c|}
\hline \multicolumn{1}{|c|}{ Particular } & Excellent & Good & $\begin{array}{c}\text { Neither Good nor } \\
\text { Bed }\end{array}$ & Moderate & Sub Standard \\
\hline Tasty \&Variety food & 85 & 64 & 22 & 19 & 10 \\
\hline Cleanliness \& Hygiene & 75 & 68 & 32 & 16 & 9 \\
\hline Water's service & 84 & 62 & 34 & 13 & 7 \\
\hline
\end{tabular}

Source: Questionnaire, Question no.16

Table 1.4 indicates that as per majority of respondent's quality of food services are either excellent or good, as per only few respondents it is either moderate or sub standard.

Table-1.5: Distribution of respondents according to their education and opinion about quality of food services.

\begin{tabular}{|c|c|c|c|c|}
\hline \multirow{2}{*}{ Education } & \multicolumn{2}{|c|}{ Opinion about quality of food services. } & \multirow{2}{*}{ Total } \\
\cline { 2 - 5 } & Satisfied & Neutral & Dissatisfied & \\
\hline Metric & 12 & 9 & 11 & $\mathbf{3 2}$ \\
\hline Graduate & 43 & 2 & 5 & $\mathbf{5 0}$ \\
\hline
\end{tabular}




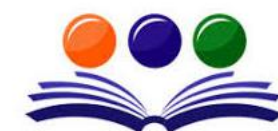

GRAND ACADEMIC PORTAL RESEARCH JOURNALS
A GLOBAL JOURNAL OF SOCIAL SCIENCES

( ISSN - 2581-5830 )

Impact Factor: SJIF - 4.998, IIFS - 4.375

\begin{tabular}{|c|c|c|c|c|}
\hline Post graduate & 39 & 2 & 7 & $\mathbf{4 8}$ \\
\hline Professional & 11 & 9 & 12 & $\mathbf{3 2}$ \\
\hline Diploma & 23 & 7 & 8 & $\mathbf{3 8}$ \\
\hline Total & $\mathbf{1 2 8}$ & $\mathbf{2 9}$ & $\mathbf{4 3}$ & $\mathbf{2 0 0}$ \\
\hline
\end{tabular}

Source: Questionnaire, Question no. 7 \& 16.

Ho: There is no significant difference between education of respondents and their opinion about quality of food services.

$\mathrm{H}_{1}$ : There is significant difference between education of respondents and their opinion about quality of food services.

Chi square value $=40.3$ with $\mathrm{DF} 8, \mathrm{X}^{2} \mathrm{c}=40.3$, at $5 \%$ level of significance with $8 \mathrm{DF} \mathrm{X}^{2} \mathrm{~T}=15.507$

Here, $\mathrm{X}^{2} \mathrm{C}>\mathrm{X}^{2}$, hence Ho is rejected. So we can say that there is significant difference between education of respondents and their opinion about quality of food services.

Table-1.6: Distribution of respondents according to their education and opinion about tourism promotion facilities.

\begin{tabular}{|c|c|c|c|c|}
\hline \multirow{2}{*}{ Education } & \multicolumn{2}{|c|}{ Opinion about tourism promotion facilities. } & \multirow{2}{*}{ Total } \\
\cline { 2 - 5 } & Satisfied & Neutral & Dissatisfied & \\
\hline Metric & 8 & 11 & 13 & $\mathbf{3 2}$ \\
\hline Graduate & 37 & 5 & 8 & $\mathbf{5 0}$ \\
\hline Post graduate & 36 & 4 & 7 & $\mathbf{4 8}$ \\
\hline Professional & 18 & 7 & 6 & $\mathbf{3 2}$ \\
\hline Diploma & 25 & 7 & $\mathbf{4 2}$ & $\mathbf{2 0 0}$ \\
\hline Total & $\mathbf{1 2 4}$ & $\mathbf{3 4}$ & & \\
\hline
\end{tabular}

Source: Questionnaire, Question no. 7 \& 18.

Ho: There is no significant difference between education of respondents and their opinion about tourism promotion facilities.

$\mathrm{H}_{1}$ : There is significant difference between education of respondents and their opinion about tourism promotion facilities.

Chi square value $=26.9$ with $\mathrm{DF} 8, \mathrm{X}^{2} \mathrm{C}=26.9$, at $5 \%$ level of significance with $8 \mathrm{DF} \mathrm{X}^{2} \mathrm{~T}=15.507$

Here, $\mathrm{X}^{2} \mathrm{C}>\mathrm{X}^{2} \mathrm{~T}$, hence Ho is rejected. So we can say that there is significant difference between education of respondents and their opinion about tourism promotion facilities.

\section{FINDINGS}

1) From the survey of 200 respondents considering their education and type of tourist place visited; there is a variation in their opinion about the services.

2) Distribution of respondents according to type of tourist place and their education shows that there is no any impact of education on the place selection. There is no significant difference between type of tourist place and education. So Ho is accepted.

3) Distribution of respondents according to their education and opinion about transport facilities shows that as per different level of education of respondents their satisfaction or dissatisfaction level is also different. Among respondents 14 metric, 41 graduate, 39 p graduate and 24 diploma holder are satisfied while 8 metric, 4 graduate, 3 post graduate, and 5 diploma holder are neutral and remaining are dissatisfied. There is significant difference between education level and their opinion about transport facilities. So Ho is rejected and $\mathrm{H}_{1}$ is accepted.

4) There is significant difference in education level and their opinion about facilities of tourist complexes. From the respondents 13 metric, 40 graduate, 41 post graduate, 12 professional, 21 diploma holders are satisfied. 9 metric, 7 graduate, 5 post graduate, and 11 professional and 9 diploma holders are dissatisfied with the facilities. And remaining is neutral. So Ho is rejected and $\mathrm{H}_{1}$ is accepted.

5) There is significant difference in education level and their opinion about quality of food services. Among the respondents 12 metric, 43 graduate, 39 post graduate, 11 professional, 23 diploma holders are satisfied, 11 metric, 5 graduate, 7 post graduate, 12 professional and 8 diploma holders are dissatisfied with the facilities of quality of food services. Remaining is neutral. So Ho is rejected and $\mathrm{H}_{1}$ is accepted. 
